\title{
Cuban Subterranean Termite (proposed), Florida Dampwood Termite (old unofficial name), Prorhinotermes simplex (Hagen) (Insecta: Isoptera: Rhinotermitidae) ${ }^{1}$
}

Rudolf H. Scheffrahn, Nan-Yao Su, Brian Cabrera and William Kern, Jr. ${ }^{2}$

\section{Introduction}

Prorhinotermes is a tropical genus of some 20 species with the greatest diversity in Southeast Asia. Three species of Prorhinotermes occur in the New World including Prorhinotermes simplex (Hagen). This species is endemic to and known only from southeastern Florida, western Cuba, Jamaica, and Puerto Rico. Species of Prorhinotermes generally live in or near coastal habitats and on islands.

Over the years, common names of some of Florida's termites have lead to confusion. The old unofficial common name for P. simplex, "Florida dampwood termite," is now designated as a collective name for three species of Neotermes (Family Kalotermitidae) found in central and southern Florida. Although P. simplex does not forage in or above the soil as frequently or as extensively as other species of subterranean termites in Florida, it is a true subterranean termite that tends to locate nests in dead logs and stumps. Neotermes spp., on the other hand, are truly restricted to wood that has a high moisture content. Neotermes spp. do not forage in the soil nor do they build above-ground foraging or flight tubes.

\section{Distribution}

Prorhinotermes simplex is found in subtropical woodlands, mangroves, and urban settings on the southeast coast of Florida from the Florida Keys northward to the island of Palm Beach. In Dade and Broward Counties, colonies of $P$. simplex have been collected as far inland as 7 miles and often in areas near waterways, rivers, and canals containing either fresh, brackish, or salt water.

\section{Description and Identification}

Colonies of $P$. simplex, like other subterranean termites, consist of three primary castes: the reproductives (king, queen, and unmated winged forms called alates), soldiers, and workers. Multiple ergatoid (worker-like) reproductives have been observed in $P$. simplex colonies.

1. This document is EENY-282, one of a series of Featured Creatures from the Entomology and Nematology Department, Florida Cooperative Extension Service, Institute of Food and Agricultural Sciences, University of Florida. Published: January 2003. This document is also available on Featured Creatures Website at http://creatures.ifas.ufl.edu. Please visit the EDIS Website at http://edis.ifas.ufl.edu.

2. Rudolf H. Scheffrahn, Nan-Yao Su, Brian Cabrera and William Kern, Jr., Entomology and Nematology Department, Institute of Food and Agricultural Sciences, University of Florida, Ft. Lauderdale, FL.

The Institute of Food and Agricultural Sciences (IFAS) is an Equal Employment Opportunity - Affirmative Action Employer authorized to provide research, educational information and other services only to individuals and institutions that function without regard to race, creed, color, religion, age, disability, sex, sexual orientation, marital status, national origin, political opinions or affiliations. For information on obtaining other extension publications, contact your county Cooperative Extension Service office. Florida Cooperative Extension Service / Institute of Food and Agricultural Sciences / University of Florida / Larry R. Arrington, Interim Dean 


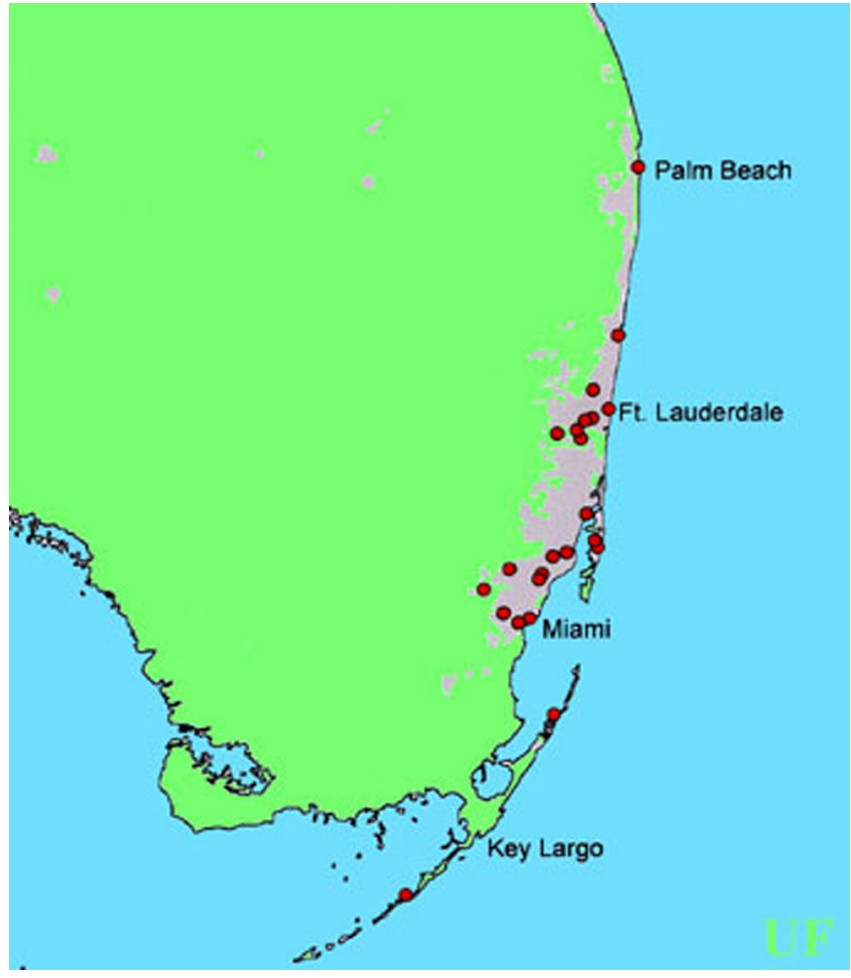

Figure 1. Collection sites of the termite Prorhinotermes simplex (Hagen) in Florida (records from 1985-2002). Credits: Rudolf H. Scheffrahn, University of Florida

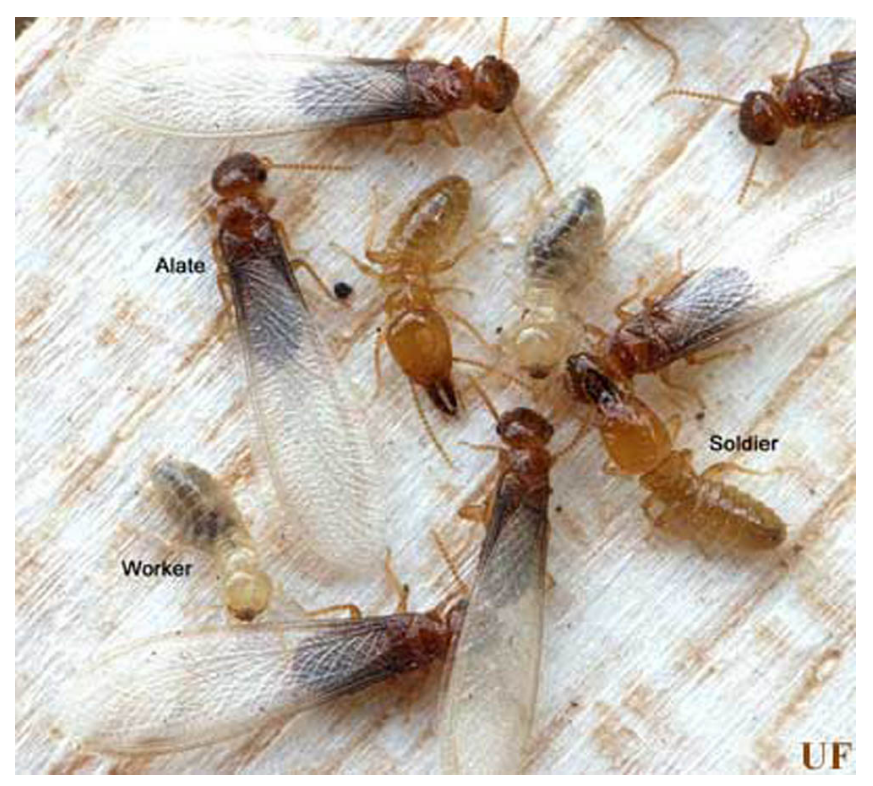

Figure 2. Castes in a Prorhinotermes simplex (Hagen) termite colony. Credits: Rudolf $\mathrm{H}$. Scheffrahn, University of Florida

Soldiers of $P$. simplex can be mistaken for Coptotermes spp. because of their similar sizes and ovoid head capsules when viewed from above. Species of Prorhinotermes can be differentiated from Coptotermes by the size and position of the fontanelle, an opening in the head. In Prorhinotermes, the fontanelle is minute and opens to the dorsal surface. In Coptotermes, the fontanelle is large and opens forward above the mouth parts.

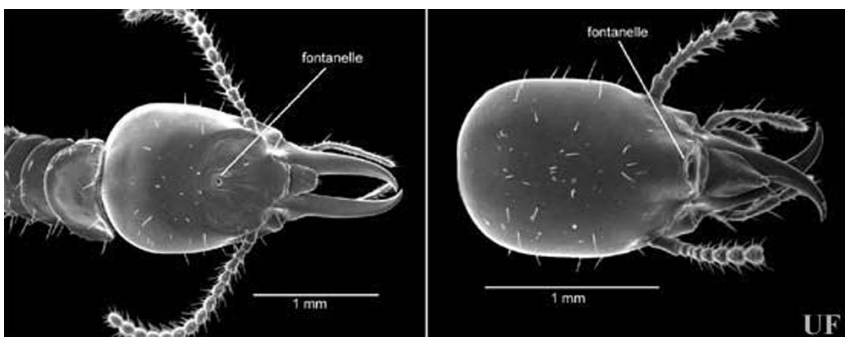

Figure 3. Scanning electron micrograph of termite soldier head capsules of Prorhinotermes simplex (Hagen) and Coptotermes havilandi Holmgre (right) showing location of fontanelle. Credits: Rudolf H. Scheffrahn, University of Florida

The alate is the caste most likely to be encountered by homeowners or pest management professionals. The body is reddish-brown and similar in size (length with wings 8.5-10.5 mm) to the West Indian drywood termite, Cryptotermes brevis (Walker). Unlike drywood termites, however, the fore wing of P. simplex has two unbranched veins in the leading (costal) margin of the wing. The $P$. simplex fore wing also differs from other subterranean termites in Florida in that it is broad in the middle due to the high arch in the costal margin. It also lacks a median vein thus leaving only a single branched vein, the cubitus, below the costal margin.

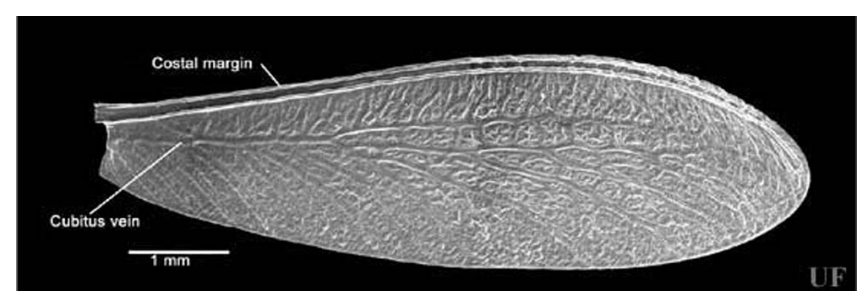

Figure 4. Scanning electron micrograph of the Prorhinotermes simplex (Hagen) termite alate fore wing. Credits: Rudolf H. Scheffrahn, University of Florida

\section{Biology}

The biology of $P$. simplex is not well known although it likely follows that of other subterranean termites. Some research on $P$. simplex has focused on the unique chemistry of the soldiers' defensive secretion. The clear secretion, emitted from the fontanelle, contains small quantities of nitroolefins that are toxic to ants and to other termites. These secretions differ from the large quantities of sticky 
and milky, but largly nontoxic, mucopolysaccharides found in some Coptotermes spp.

Flight records in southeast Florida range from September to February with peak activity in November and December. Flights occur at dusk or at night and, like most nocturnal flying insects, the alates are attracted to lights and video displays.

\section{Pest Status}

The limited habitat area and low density of $P$. simplex colonies relegate these termites to minor pest status. Structural damage is usually limited to wood in contact with or near soil. Most colonies will be centered in stumps and logs that, when hollowed, are filled with a damp, hard nest material called carton. The greatest likelihood of nuisance reports with $P$. simplex occurs during dispersal flights when indoor flight tubes and fecal spotting are constructed before alates emerge.

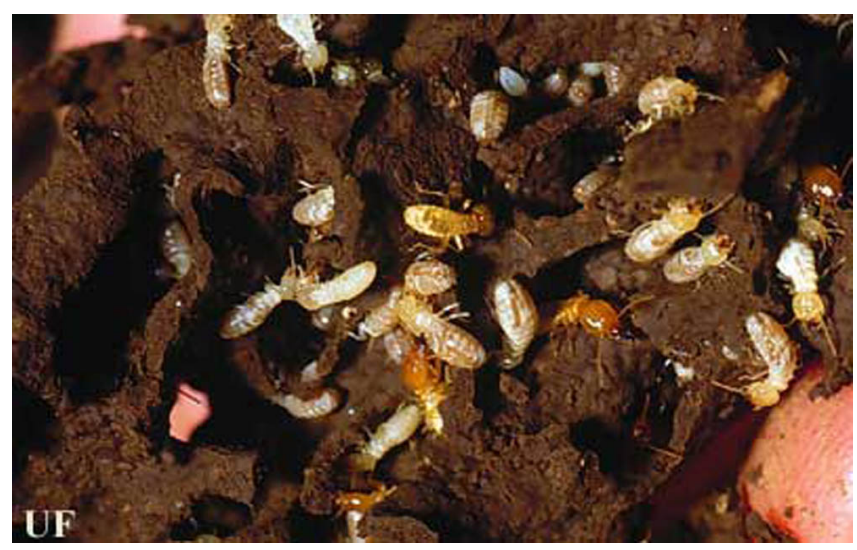

Figure 5. Prorhinotermes simplex (Hagen) termite carton material removed from inside dead tree trunk. Credits: Rudolf H. Scheffrahn, University of Florida

\section{Management}

Because of their limited foraging range, $P$. simplex can be controlled using residual chemicals within wall voids where flight tubes appear and around the foundation nearest to indoor activity. Although there is no reason termite baits should not be effective, there are no data to support the use of baits on $P$. simplex.

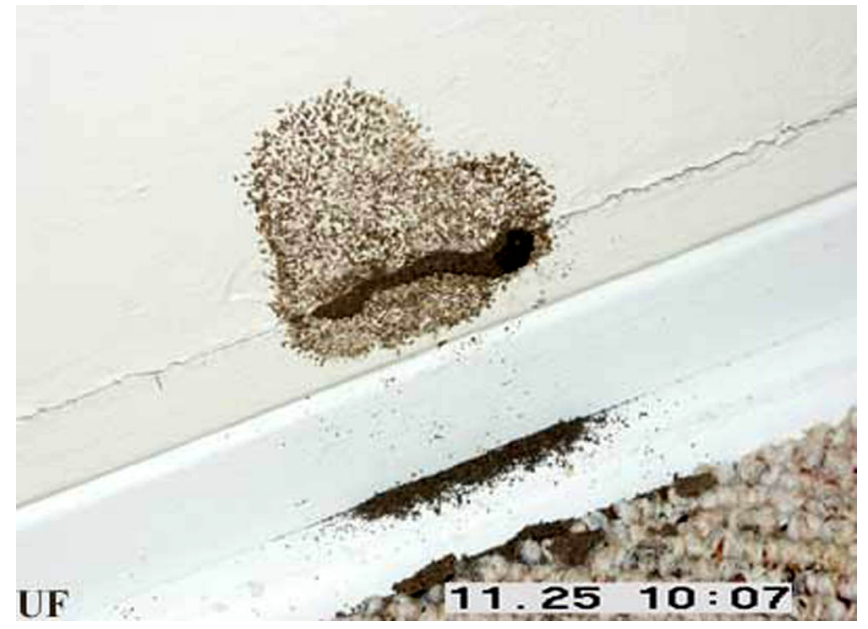

Figure 6. Prorhinotermes simplex (Hagen) termite flight tube emerging from interior wall above molding. Credits: Rudolf H. Scheffrahn, University of Florida

\section{Selected References}

Miller EM. 1949. A handbook on Florida termites. University of Miami Press, Coral Gables. 30 pp.

Scheffrahn RH, Su N-Y. 1994. Keys to soldier and winged adult termites (Isoptera) of Florida. Florida Entomologist 77: 460-474.

Scheffrahn RH, Su N-Y. Key to termite soldiers of Florida. Ft. Lauderdale Research Report 96-2.

Scheffrahn RH, Su N-Y. Key to winged termites of Florida. Ft. Lauderdale Research Report 96-3. 